\title{
Effect of postharvest sodium benzoate treatment on some fruit parameters of two organic apple cultivars
}

\author{
Molnár, B. ${ }^{1}$, Szabó, Sz. ${ }^{2}$, Veres, Á. ${ }^{1}$, Holb, I. J. ${ }^{1,3}$ \\ ${ }^{1}$ Instutite of Horticulture, University of Debrecen, Böszörményi út 138, 4032 Debrecen, \\ ${ }^{2}$ Department of Physical Geography and Geoinformatics, Faculty of Science and Technology, \\ University of Debrecen, Egyetem tér 1, 4032 Debrecen, Hungary \\ ${ }^{3}$ Instutite of Horticulture, University of Debrecen, Böszörményi út 138, 4032 Debrecen, and Hungarian Academy of Sciences, \\ Plant Protection Institute, Herman Ottó út 15, 1022 Budapest, Hungary, \\ Author for correspondence: holbimre@gmail.com
}

\begin{abstract}
Summary: The aim of this study was to investigate the effect of postharvest sodium-benzoate treatment on some fruit parameters of two organic apple cultivars ('Topaz' and 'Florina'). Assessments were made at three times during storage: 17 November 2019, 20 December 2019 and 23 January, 2020. During every assessment dates, each fruit was observed separately, and determined the proportion of i) healthy fruits (\%), ii) post-harvest fruit rot diseases iii) fruits with mechanical injury (\%), iv) fruit with russetting (\%), v) damage of codling moth and vi) Ca-deficiency symptoms. In addition, fruit weight $(\mathrm{g})$ was measured at each assessment date. Sodium benzoate reduced the fruit decay and the proportion of healthy fruit was higher in this treatment compared to water treated fruit. This effect could be seen in all assessment dates and on both cultivars. Effects on other parameters were various according to cultivar and assessment dates. Loss of fruit weight was similar in both treatments and cultivars compared to control treatment.
\end{abstract}

Molnár B., Szabó Sz., Veres Á., Holb I. J. (2020): Effect of postharvest sodium benzoate treatment on some fruit parameters of two organic apple cultivars. International Journal of Horticultural Science 26: 35-37. https://doi.org/10.31421/IJHS/26/2020/8004

Key words: apple, sodium benzoate, organic production, postharvest, fruit decay, fruit weight

\section{Introduction}

In Hungary, apple production is the leading crop among all cultivated fruits (Papp, 2003, 2004). Production area was 31838 ha and total fruit production was 678.775 tonnes in 2018 (KSH, 2018). The area of organic production was $10.2 \%$ of the total Hungarian apple production in 2017 (KSH, 2018). As the use of chemicals is inhibited in organic production, cultivar susceptibility plays a major role in disease management. Scab resistant cultivars such as 'Topaz' 'Relinda' and 'Florina' are the most often planted cultivars in organic production in Hungary (Soltész, 1998; Fekete \& Szabó, 2014). Annual stored apple fruits are about 50-60 000 tonnes from which 3503 tonnes are lost due to postharvest decays (KSH, 2018).

In Hungarian organic production, none of the synthetic chemicals are permitted to use during pre- and postharvest fruit production (Holb \& Scherm, 2008; Biokontroll, 2020). Therefore, the stored fruits are more likely to suffer from postharvest decays (Soltész, 1998; Holb, 2004ab). Most nonchemical management options against postharvest fruit decays had low to moderate efficacy under cold storage and shelf-life conditions (Ezzat et al., 2017; Wang et al., 2019; Shemy et al., 2020) Some of the food additives showed promising option to reduce postharvest fruit decay (Wu et al. 2015), therefore, we supposed that sodium benzoate can delay fruit decay during storage.

The aim of this study was to investigate the effect of postharvest sodium benzoate treatment on some fruit parameters of two organic apple cultivars.

\section{Materials and methods}

\section{Orchard site}

The study was conducted in Eperjeske, Szabolcs-SzatmárBereg County in 2019-2020. The harvested and later stored apples were originated from a 0.95 ha orchard plot planted in 2003 on M26 rootstock. Orchard was under organic production since it's plantation in 2003. The plot consists of two different cultivars. Trees were planted in a mid-density training system, one of the two cultivars ('Topaz') in $6 \times 3.5 \mathrm{~m}$, and the other ('Florina') in $6 \times 4 \mathrm{~m}$ spacings. All cultivars are resistant to apple scab, and are widely used in organic production, additionally Orchard soil type was non-carbonated humic sand, soil alkalinity is extremely acidic $(\mathrm{pH}=4.07)$. The orchard is nonirrigated. Storage facility is a non-controlled atmosphere (conventional) storage room safe from sunshine and frost, located $2 \mathrm{~km}$ away from the orchard.

\section{Storage and sodium benzoate treatment}

Traditional storage house was used for the treatments. The study was conducted on two apple cultivars, one sodium benzoate treatment and at three assessment date during storage. A water treatment was used as a control. Each treatment consisted of a minimum of 30 apple fruit with a normal size. Each treatment was repeated three times. Half of the apples were treated with sodium benzoate. A normal concentration used as for food additive: the solution concentration was $0.02 \mathrm{w} / \mathrm{v} \%$. Other half of the apples were used as water control. Fruit were 
dipped into a solution of sodium benzoate for two minutes, and each apple was dipped in the solution separately and then they were stored in baskets after they naturally dried. Apples were treated and stored right after harvest. Harvesting time was 10 and 30 September for 'Florina' and 'Topáz', respectively. The apples were transported to the storage house for 5 months.

\section{Assessments}

Assessments were made at three times during storage: 17 November 2019, 20 December 2019 and 23 January, 2020. During every assessment dates, each fruit was observed separately, and determined the proportion of i) healthy fruits $(\%)$, ii) post-harvest fruit rot diseases iii) fruits with mechanical injury (\%), iv) fruit with russetting (\%), v) damage of codling moth and vi) Ca-deficiency symptoms. In addition, fruit weight (g) was measured at each assessment date.

\section{Data analysis}

Each treatment was subjected to analyses of variance (ANOVA) in order to evaluate the significant effect of sodium benzoate on fruit parameters at each assessment date. Means were separated at $\mathrm{P}=0.05$ probability level using LSD-test.

\section{Results}

\section{Fruit parameters of 'Topaz'}

On 17 November, there were $30 \%$ more healthy fruits in the treated group than in the untreated one. Other parameters such as incidences of diseased fruits, russetting, codling moth damage and $\mathrm{Ca}$-deficiency were higher in the untreated group. In case of mechanical injury nearly the same incidence was observed in both groups of fruit (Figure 1/A). Nearly one month later, the incidence of healthy fruits were higher in the untreated group (Figure 1/B). There were no sign of mechanical injury nor russetting at this assessment date in the control treatment. Codling moth damage and Ca-deficiency symptoms appeared in both groups. At 23 January, the proportion of healthy fruits were higher in the sodium benzoate treatment. Storage fruit rot and mechanical injury incidence were higher in the untreated group. Codling moth damage was higher in the sodium-benzoate group (Figure 1/C).

\section{Fruit parameters of 'Florina'}

On 17 November, healthy fruit incidence was the same $(46 \%)$ in both treatments. Fruit rot disease and mechanical injury incidence was higher in the untreated group. Incidences of $\mathrm{Ca}$ deficiency and russeted fruits were the same in both groups. Codling moth damage occured only in the treated group (Figure $1 / \boldsymbol{A}$ ). On 20 December, there were more healthy fruits in the treated group than in the untreated. Fruit rot incidence was twice higher in the untreated group. Injury incidence was lower in the sodium-benozate treated group. The Ca-deficiency symptoms occured equally in each group. Codling moth damage did not change compared to the previous assessment (Figure 2/B). At 23 January, incidences of healthy and diseased fruits were similar in the two groups. Russetting and injury were higher in control group. Codling moth incidence did not changed in the sodium-benzoate treated group (Figure 2/C).
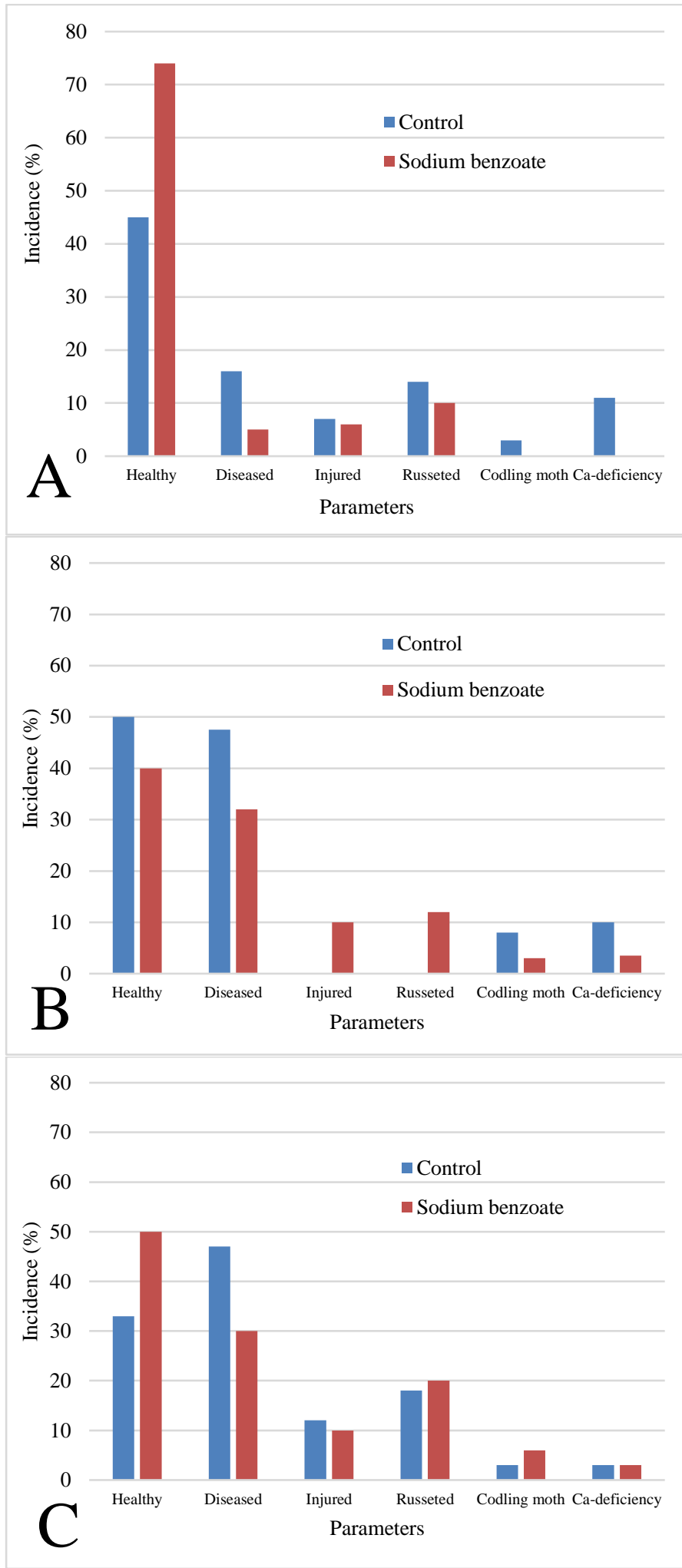

Figure 1. Incidence of selected fruit parameters of 'Topáz' in control and sodium benzoate treatments assessed at 17 November, 2019 (A), 20 December, 2019 (B) and 23 January, 2020 (C).

\section{Fruit weight of 'Topaz' and 'Florina'}

Fruit weight decreased with assessment dates due to water loss of the fruits on both cultivars (Table 1). Although, loss of fruit wieght was larger in the sodium benzoate treatments compared to control treatment on both cultivars, differences were not significant at $\mathrm{P}=0.05$ level. 
Table 1. Fruit weight (g) of 'Topaz' and 'Florina' in control and sodium benzoate treatments assessed at 17 November, 2019, 20 December, 2019 and 23 January, 2020.

\begin{tabular}{lccc}
\hline Fruit weight $(\mathrm{g})$ & \multicolumn{3}{c}{} \\
\cline { 2 - 4 } & 17 Nov & 20 Dec & 23 Jan \\
\hline Topaz & & & \\
Control & 155.2 & 152.8 & 152 \\
Sodium benzoate & 151.3 & 147.9 & 145.8 \\
Florina & & & \\
Control & 182 & 178.5 & 177.2 \\
Sodium benzoate & 182.8 & 177.9 & 175.3 \\
\hline
\end{tabular}
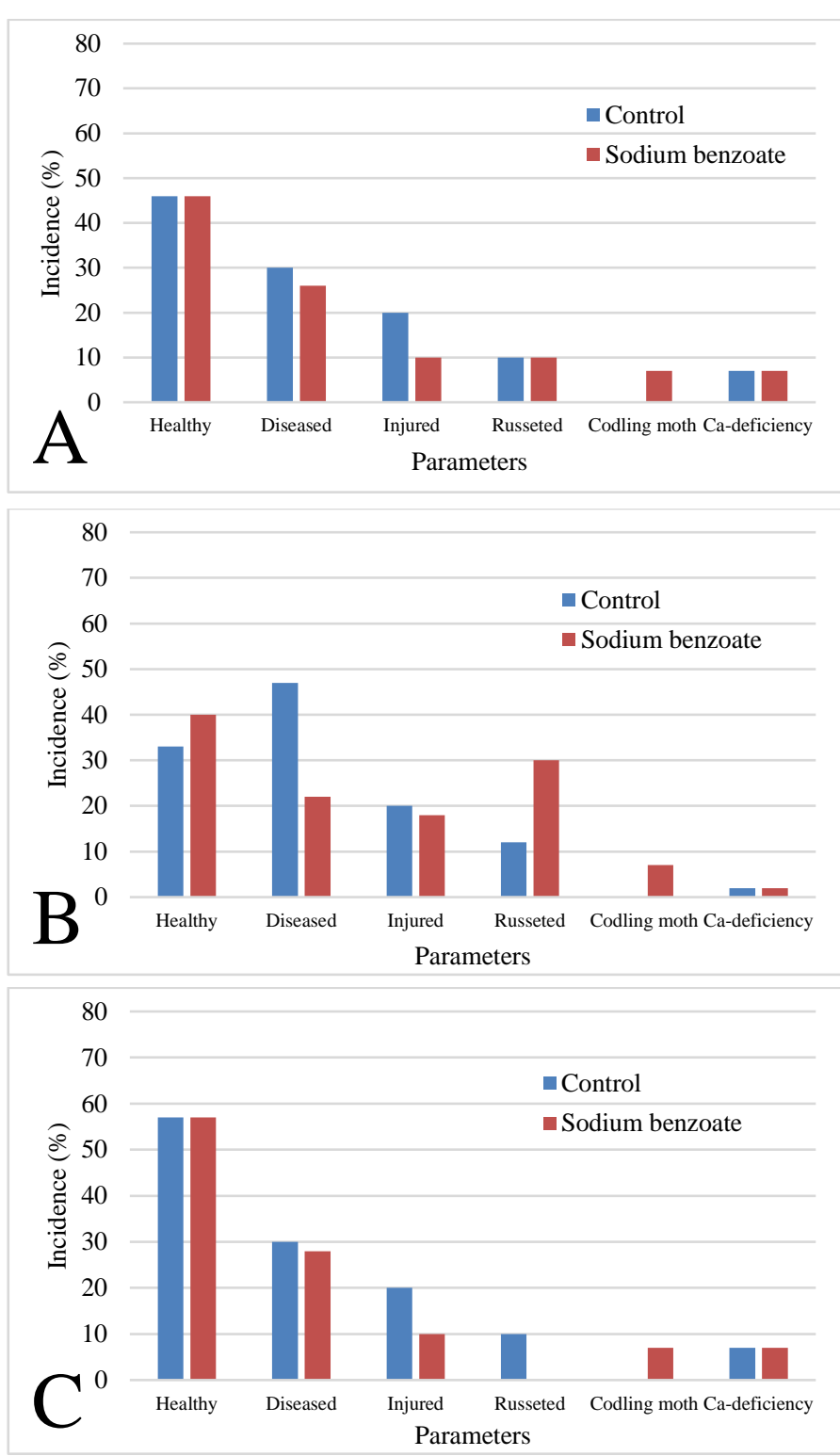

Figure 2. Incidence of selected fruit parameters of 'Florina' in control and sodium benzoate treatments assessed at 17 November, 2019 (A), 20 December, 2019 (B) and 23 January, 2020 (C).

\section{Conclusions}

This study showed that sodium benzoate reduced the fruit decay and the proportion of healthy fruit was higher in this treatment compared to water treated fruit. This effect could be seen in all assessment dates and both cultivars. Effects on other parameters were various according to cultivar and assessment dates. Loss of fruit weight was similar in both treatments and cultivars compared to control treatment.

\section{Acknowledgements}

This work was partly financed by the Hungarian Scientific Research Fund (K 131478) by the European Union and the State of Hungary, co-financed by the European Social Fund in the framework of TÁMOP-4.2.4.A/ 2-11/1-2012-0001 'National Excellence Program' under the project No. A2-SZJ-TOK-130061, and by the Thematic Excellence Programme of the Ministry for Innovation and Technology in Hungary (ED_18-12019-0028), within the framework of the climate change thematic programme of the University of Debrecen.

\section{References}

Biokontroll (2020): Ellenőrzés és tanusítás a biokontroll feltételrendszerében. https://www.biokontroll.hu/

Ezzat, A., Ammar, A., Szabó, Z., Nyéki, J., Holb, I. (2017): Postharvest treatments with methyl jasmonate and salicylic acid for maintaining physico-chemical characteristics and sensory quality properties of apricot fruit during cold storage and shelf-life. Polish Journal of Food and Nutrition Sciences 67(2): 159-66.

Fekete, Z., Szabó T. (2014): Biotermesztésre alkalmas almafajták. Biokultúra 25 (4):18-23.

Holb, I. J. (2004a): The brown rot fungi of fruit crops (Monilinia spp.): II. Important features of their epidemiology. International Journal of Horticultural Science, 10(1), 17-33. https://doi.org/10.31421/IJHS/10/1/435

Holb, I. J. (2004b): The brown rot fungi of fruit crops (Monilinia spp.): III. Important features of disease management. International Journal of Horticultural Science, 10(4), 31-49. https://doi.org/10.31421/IJHS/10/4/507

Holb, I. J., Scherm, H. (2008): Quantitative relationships between different injury factors and development of brown rot caused by Monilinia fructigena in integrated and organic apple orchards. Phytopathology, 98(1), 79-86.

KSH (2018): 2018. évi mezőgazdasági és kertészeti statisztikai adatok. https://www.ksh.hu/docs/hun/xstadat/xstadat_eves/

Papp, J. (ed.) (2003): Gyümölcstermesztési alapismeretek. Mezőgazda Kiadó, Budapest.

Papp, J. (ed.) (2004): A gyümölcsök termesztése. Mezőgazda Kiadó, Budapest.

Shemy, M. A. El, \& Shemy, M. A. El. (2020): Effect of some essential oils, salts and salicylic acid on reducing decay, keeping quality and prolonging shelf-life of canino apricot fruits. Menoufia J. Plant Prod, 5, 111-128.

Soltész, M. (ed.) (1998): Gyümölcsfajta-ismeret és-használat. Mezőgazda Kiadó, Budapest.

Wang, H., Wu, Y., Yu, R., Wu, C., Fan, G., Li, T. (2019): Effects of postharvest application of methyl jasmonate on physicochemical characteristics and antioxidant system of the blueberry fruit. Scientia Horticulturae, 258.

Wu, B., Guo, Q., Wang, G. Xia, Peng, X. Yuan, Wang, J. de, Che, F. (2015): Effects of different postharvest treatments on the physiology and quality of 'Xiaobai' apricots at room temperature. Journal of Food Science and Technology, 52(4), 2247-2255. 